\title{
Seasonal variation in waterbird assemblage in the Mahango Game Reserve, north-eastern Namibia
}

\author{
Grzegorz Kopij ${ }^{1,2}$ and Mark Paxton ${ }^{3}$ \\ 'Department of Integrated Environmental Science, University of Namibia, Ogongo Campus, Namibia \\ ${ }^{2}$ Department of Vertebrate Ecology, Wroclaw University of Environmental \& Life Sciences, ul. Kozuchowska 5b, 51-631 Wroclaw, Poland \\ ${ }^{3}$ Shamvura Camp, Rundu, Namibia
}

\begin{abstract}
There are few African studies on seasonal changes in the waterbird assemblages in river ecosystems. Tropical freshwater ecosystems are regarded as more stable habitats over the year than terrestrial ones. The same could be expected in regard to the bird fauna associated with such ecosystems. In order to test if waterbird asembalges followed the stable ecosystem paradigm a study was undertaken in the Okavango River, in the Mahango Game Reserve, north-eastern Namibia. Counts of all waterbirds were conducted in wet and dry seasons during 2001-2006. In total, 88 waterbird species were recorded. In wet seasons the number was slightly lower $(N=75)$ than in dry seasons $(N=78)$ (chi-square test: $\left.\chi^{2}=0.06 ; p>0.05\right)$. The total number of individuals of all resident species recorded in wet seasons was unexpectedly much lower in wet $(N=9979)$ than in dry seasons $(N=15501)$ (chi-square test: $\left.\chi^{2}=1196 ; p<0.01\right)$. In wet seasons, Collared Pratincole, Blacksmith Lapwing, African Openbill Stork and African Darter dominated (58.8\%), while in the dry season: White-faced Duck, Spur-winged Goose, African Skimmer, African Reed Cormorant, African Darter and Squacco Heron contributed $60.8 \%$ to the overall abundance. Diversity indices were similar in both seasons.
\end{abstract}

Keywords: population trends, wetlands, Namibia

\section{INTRODUCTION}

In comparison with terrestrial habitats, tropical freshwater ecosystems are regarded as more stable over the year, as one of the most important ecological factors, water, is not a limiting factor in this case. The same could be expected in regard to the bird fauna associated with such ecosystems, but waterbirds are known to be seasonally highly mobile under such conditions (Cumming et al., 2012). Some are resident throughout the year, others are intra-African migrants or nomads; still others are African or Palearctic non-breeding visitors; and some are vagrants which appear only occasionally. There is not enough information, however, about waterbird communities in tropical ecosystems, especially in arid areas, to be able to detect any pattern of changes (Cumming et al., 2012).

Kelejta-Summers et al. (2001) studied year-to-year and seasonal changes in waterbird communities at the Cape Flats Sewage Treatment Works in Strandfontein near Cape Town. Swanepoel et al. (2009) studied year-to-year changes in waterbirds in an impoundment, the Theewaterskloof Dam in the Western Cape, South Africa. Mundava et al. (2013) investigated year-to-year and seasonal changes in the composition and abundance of waterbirds in two artificial lakes (Chivero and Manyame) near Harare, Zimbabwe. Cumming et al. (2013) studied seasonal changes in waterbirds in a natural lake and wetlands at Barberspan, South Africa. All of these standing and mostly artificial freshwater ecosystems constitute, however, quite different ecological settings in comparision with a large perennial river.

\footnotetext{
* To whom all correspondence should be addressed. e-mail: gkopij@unam.na Received 9 December 2017, accepted in revised form 3 April 2019.
}

There are very limited studies from Africa on seasonal changes in the waterbird assemblages in riverine ecosystems. The water regime in rivers in the tropical and subtropical regions of Africa changes significantly over the years, influencing the nutrient content of water and consequently also bird fauna. In the wet season, a number of Palearctic and intra-African species are expected to occur in such habitats. It is therefore interesting to investigate their impact on the local waterbird fauna. Other possible drivers of waterbird seasonal variation can be the prevailing weather conditions (especially amount of rainfall) in the neighbouring regions, which may force some waterbirds to vacate their habitats during prolonged droughts and occupy the areas with perennial rivers. On the other hand, exccesive flooding may force the local resident birds to vacate their territories and look for rivers with lower water levels. Human activities may further contribute to the variation, for example, crop production (maize, wheat, groundnuts), fishing, water extraction for irrigation in the dry season, and influx of fertilizers and sewage to the river.

The aim of this study was to compare the species composition, diversity, abundance and dominance of waterbird species occurring in a subtropical river in wet and dry seasons. In addition to these, changes in main ecological guilds of waterbirds in these two seasons were investigated. This will help to identify possible drivers of waterbir species composition and their abundance. We predict higher diversity and abundance of waterbirds in dry season, as we consider the river as a refugium for waterbirds in the dry season, given the surrounding arid environment.

\section{STUDY AREA}

The study was conducted in the Mahango Game Reserve, which is situated in the panhandle of the Okavango River Delta in the Kavango East region, north-east Namibia $\left(18^{\circ} 12^{\prime} \mathrm{S}, 24^{\circ} 41^{\prime} \mathrm{E}\right)$. 
The Mahango Game Reserve was established in 1988 and has an area of $245 \mathrm{~km}^{2}$. It consists of a vast floodplain and associated riparian forest. The reserve is stocked with diverse ungulate species. There are 200 hippopotami Hippopotamus amphibius, 300 elephants Loxodonta africana, 500 buffalos Syncerus caffer, and about 10 antelope species (Mendelsohn and El Obeid, 2004; own observ.). The flood reaches heights of 3 to $4 \mathrm{~m}$ above the low water level in November. The mean annual rainfall in the study area is $550-600 \mathrm{~mm}$, with approx. $80 \%$ falling between December and March (Mendelsohn and El Obeid, 2009). Annual rainfall varies substantially from year to year.

The river forms a meandering channel, $2-6 \mathrm{~km}$ wide, in the reserve. The riverbanks are covered with extensive marshlands comprising tall grasses (Poaceae), sedges (Juncidae), reeds Phragmites australis (in the form of reedbeds a few hundreds of meters in width) and papyrus Cyperus papyrus. The riparian forest is composed mainly of Garicinia, Sclerocarya, Diospyros, Vachellia/Senegalia, Grewia, Pterocarpus, Ricinodendron, Ziziphus, Baikiaea, Baphia, Phoenix and Adansonia. Bethune (1991) recorded over 869 vascular plant species from 88 families in the Okavango Valley. The river valley forms wetlands connected to the main channel with numerous small channels well vegetated with papyrus, rushes and sedges.

The annual flood cycle is the most prominent feature of the Okavango River (Mendelsohn and El Obeid, 2009). It influences the nutrient content in the water and subsequently all life in the river and the valley. The total volume of water passing in Mukwe ranges from appox. $5607 \times 10^{6} \mathrm{~m}^{3}$ to approx. $15354 \times 10^{6} \mathrm{~m}^{3}$ per annum (Mendelsohn and El Obeid, 2003, 2004). The highest river flow is from January to March, the lowest from September to October. In November the water level is at its lowest, and in April at its highest; on average there is a 3 or 4 times height difference between November and April but this can reach $6 \mathrm{~m}$ during extreme flooding events. The long-term average (1948$1998)$ is $9594 \times 10^{6} \mathrm{~m}^{3}$. Flows are much more stable in the dry than in the rainy season. There is also extensive flooding in the valley (Bethune, 1991; Cumming et al., 2012).

\section{METHODS}

The main channel surveyed was $50-200 \mathrm{~m}$ in width and approx. $28 \mathrm{~km}$ long. The main river channel has sandbanks and numerous vegetated islands. All waterbird species were counted, except for passerines such as wagtails, Motacilla spp., and reed warblers, Acrocephalus spp. The following waterbird groups were distinguished: grebes (Podicipedidae), cormorants (Phalacrocoracidae), pelicans (Pelecanidae), herons and egrets (Ardeidae), storks (Ciconiidae), ibises and spoonbills (Threskiornithidae), hamerkops (Scopidae), ducks and geese (Anatidae), cranes (Gruidae), rails (Rallidae), waders (Charadriiformes), kingfishers (Alcedidae) and raptors in the family Accipitridae which are associated with wetlands (Circus spp., Pandion haliaetus, Haliaeatus vocifer).

The line transect method was applied for counting birds (Bibby et al., 1992). Single counts were conducted in the dry season and wet season during the years 2001-2006. Counts were conducted during the whole day, i.e., between 8:00 and 9:00 and 15:00 and 16:00, usually under calm and cloudless weather.

The survey was carried out through the main river channel with a hover boat. The secondary small channels were also surveyed with the boat. All inundated places outside the main river channel were surveyed on foot. The same route was followed each year. Observations were aided with binoculars $(10 \times 50$ and $8 \times 30)$. No luring by tape recording was done.
Counts were conducted by a team of 2 to 5 persons. All seen and heard birds were identified down to species level and counted. Birds were counted separately in each encountered group. All records were kept in notebooks, following the AWC guidelines (http://www.wetlands.org).

The following parameters were used to describe the waterbird assemblages: $N$ - number of individuals recorded; $\% N$ - dominance expressed as the proportion (\%)contributed by a given species to the total number of all individuals of all species recorded.

The seasonal difference between the total number of particular species in different years was tested with the Chisquare test. All species for which the expected value was lower than 5 were excluded. Seasonal differences in the number of particular species in each year over the period 2001-2006 were tested with the Wilcoxon's matched-pairs signed rank test. This was used only when the number of matched pairs was at least 6 and the difference between the numbers was not zero. Regression analysis was applied to test the population trends over the years 2001-2006. This analysis was performed only for the more common species, the numbers for which were high enough to allow for application of the Wilcoxon's Test. For each species dominance was calculated separately for the wet and dry seasons.

Dominance was expressed as the percentage contributed by the total number of individuals of a given species recorded in the whole period 2001-2006 to the total number of all individuals of all species recorded over the same period. A 'dominant' species is defined as that which comprised $5 \%$ or more of all individuals of all species recorded, with 'subdominant' species defined as those comprising $\leq 4.99 \%$. The following guilds were distinguished:

- Foraging: OW - foraging outside wetlands, SV - short vegetation (including grass) and mud, EV - emergent vegetation (including reed, rush and lilies), SW - shallow water, DW - in or over deep water, A - aerial feeders.

- Diet: F - frugivorous, $\mathrm{V}$ - vegetarian, I - insectivorous, P - carnivorous, VI - vegetarian and insectivorous, PI carnivorous and insectivorous.

- Migration: R - resident (present throughout the year), RN - resident during breeding, otherwise nomad, LM - resident during breeding season, partial migrant after breeding, $\mathrm{N}$ nomad, AM - intra-Africa migrant, P - Palearctic migrant.

- Nesting: NB - near the bank, W - on water surface, G - on the ground; $\mathrm{V}-$ in herbaceous vegetation, $\mathrm{T}-$ in trees or shrubs, $\mathrm{H}$ - in tree holes

The following indices were used to characterize the diversity and evenness of the communities:

- Shannon's diversity index: $H^{\prime}=-\sum p_{\mathrm{i}} \log p_{\mathrm{i}}$

- where: $p_{i}$ is the proportion of individuals belonging to the $i$ th species

- Simpson's diversity index: $D=\left(\left(\sum n(n-1)\right) / N(N-1)\right.$

- where: $n$ is the total number of individuals belonging to a given species, $N$ is the total number of individuals of all species

- Pielou's evenness index: $J^{\prime}=\left(-\sum p_{i} \log p_{\mathrm{i}}\right) / \log S$

- where $p$ is the proportion of individuals belonging to the $i^{\text {th }}$ species, $\mathrm{S}$ is the total number of species. $J^{\prime}$ varies between 0 and 1 . The less variation between species in a community, the higher $J^{\prime}$ is.

- Community dominance index: $\mathrm{DI}=\left(n_{1}+n_{2}\right) / N$

- where $n_{1}, n_{2} \ldots$ are the number of individuals of the two most abundant species, $N$ is the total number of individuals of all species. 
- Cumulative dominance: sum of the percentage of all dominant species

- Sörensen's coefficient: $I=2 C / A+B$

- where $A$ is the number of bird species in the wet season, $B$ is the the number of bird species in the dry season, $C$ is the number of bird species common to both periods.

Classification and nomenclature of bird species follow Hockey et al. (2005). English and scientific names of bird species are listed in Table A1, Appendix.

\section{RESULTS}

In total, 86 waterbird species were recorded in the Okavango River in Mahango Game Reserve from 2001-2006 (Table 1A, Appendix). In the wet season the number was slightly lower $(N=75)$ than in the dry season $(N=78)$. This difference was, however, not statistically significant $\left(\chi^{2}=0.06 ; p>0.05\right)$. The total number of individuals of all resident species recorded in wet seasons was unexpectedly much lower in wet $(N=9979)$ than in dry seasons $(N=15501)$ (chi-square test: $\chi^{2}=1196 ; p$ $<0.01$ ). The Soerensen's coefficient for the comparison between the wet and dry season was $I=0.84$ (Table 1 ).

In wet seasons the dominant species included Collared Pratincole, Blacksmith Lapwing, African Openbill Stork and African Darter. Together these species comprised 58.8\% of all waterbirds recorded. In the dry season, the percentage contribution of dominant species was similar to that in the wet season $(60.8 \%)$ and included 6 species: White-faced Duck, Spurwinged Goose, African Skimmer, African Reed Cormorant, African Darter and Squacco Heron. The African Darter was, therefore, the only dominant species in both the dry and the wet season.

The group of subdominants was composed of 7 species (African Reed Cormorant, Cattle Egret, Black Egret, Squacco Heron, Cattle Egret, Water Thick-knee, African Jacana) in the wet season, and 8 species (Black Heron, Little Egret, African Openbill Stork, Sacred Ibis, African Jacana, Collared Pratincole, Blacksmith Lapwing, and Pied Kingfisher) in the dry season. Across all wet seasons the subdominant species comprised $22.2 \%$, and $24.3 \%$ across all dry seasons.

Over the period 2001-2006, differences in the number of individuals recorded in the wet and dry season were statistically significant for the following species: Goliath

TABLE 1

Parameters and Indices characterizing the waterbird assemblage in Okavango River in Mahango Game Reserve in 2001-2006. For explanations of the indices refer to the text.

\begin{tabular}{|l|c|c|}
\hline Parameter & Wet & Dry \\
\hline Number of species & 75 & 78 \\
\hline Number of individulas & 9979 & 15519 \\
\hline Simpson's Diversity Index (D) & 0.86 & 0.92 \\
\hline Shannon's Diversity Index (H') & 1.21 & 1.29 \\
\hline Pielou's Evenness Index (J') & 0.65 & 0.69 \\
\hline Number of dominant species & 4 & 6 \\
\hline Cumulative dominance (\%) & 54.88 & 60.76 \\
\hline Number of subdominant species & 7 & 8 \\
\hline Cumulative subdominance (\%) & 22.21 & 24.27 \\
\hline Community Dominance Index (DI) & 0.42 & 0.30 \\
\hline
\end{tabular}

Heron, Great Egret, Little Egret, Green-backed Heron, Rufousbellied Heron, White-faced Duck, Water Thick-knee, Longtoed Lapwing, Blacksmith Lapwing, African Fish Eagle, Pied Kingfisher and Malachite Kingfisher. However, if the total numbers of individuals for all the years are considered, then differences between wet and dry season were statistically significant for most species.

Most waterbirds were more numerous in dry than in wet seasons. Only 15 species were more numerous in the wet than in the dry season. Similar population trends in wet and dry seasons over the years 2001-2006 were recorded for 13 species, mostly for ardeids (Table A1, Appendix). For 5 species, the trend was declining in one season, and increasing in the other season. For 6 species, the population trend was stable in one season, while declining or increasing in the other season (Table A1, Appendix).

In the wet season, 12 Palearctic species comprised $8.8 \%$ of all birds recorded, while in the dry season 8 Palearctic species comprised only $0.6 \%$ (Table A1, Appendix 1). In both the wet and dry seasons there were 4 intra-African species, but in terms of the number of individuals these species were twice as numerous in the wet season than in dry season. Partial migrants were also more numerous in the wet $(22.3 \%)$ than dry season (15.7\%) (Fig. 1).

Birds foraging in shallow water were more numerous in the wet than dry season, while birds foraging in deep water were more numerous in the dry than in the wet season (Fig. 2). Insectivorous birds were more numerous in the wet than in the dry season, while piscivorous and plant-eating birds were more numerous in the dry than in the wet season (Fig. 3). Aerial feeders were more numerous in the wet than in the dry season. Birds nesting on the ground were much more numerous in the wet than in the dry season, while the reverse was recorded for birds nesting in emergent vegetation (Fig. 4).

The Simpson's and Shannon's Diversity Index as well as Pielou's Evenness Index were very similar in both seasons (Table 1).

\section{DISCUSSION}

The only other published studies, to our knowledge, on seasonal variations in waterbird assemblages in riverine ecosystems in sub-Saharan Africa to date are those of Kopij

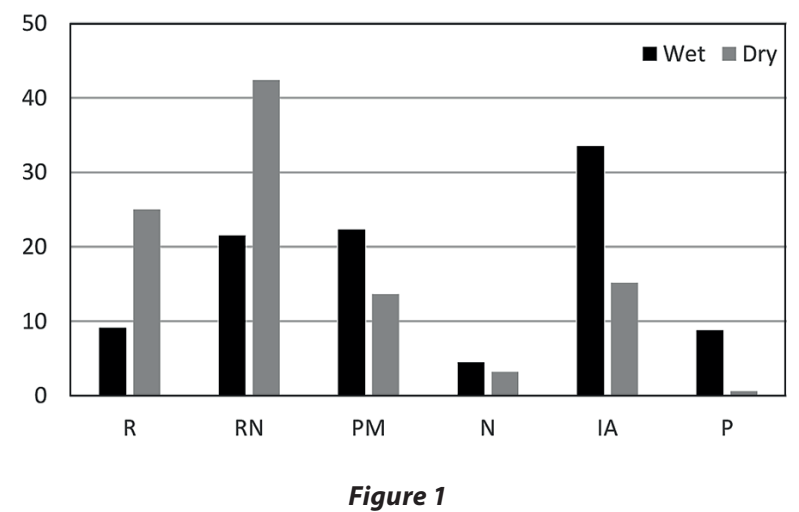

Seasonal differences in the proportions (in percentage of individuals) of main migration guilds of waterbirds in Okavango River in Mahango Game Reserve. $R$-resident (present throughout the year), $R N$-resident during breeding, otherwise nomad, $L M$ - resident during breeding season, partial migrant after breeding, $N$-nomad, AM - intra-Africa migrant, $P M-$ Palearctic migrant. 


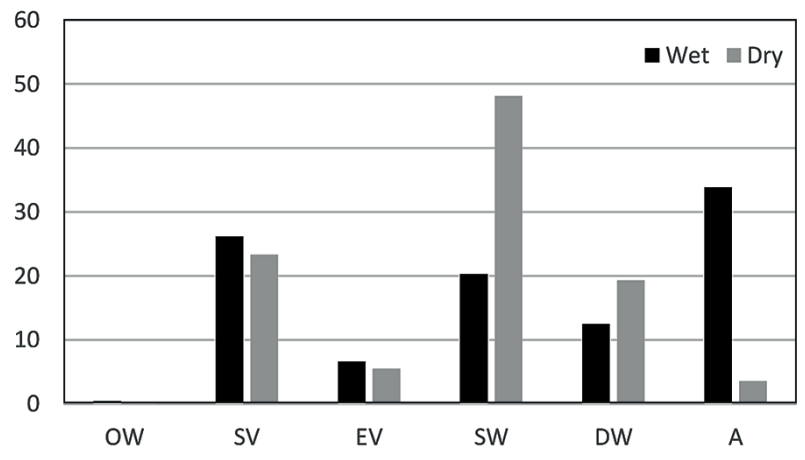

Figure 2

Seasonal differences in the proportions (in percentage of individuals) of main foraging guilds of waterbirds in Okavango River in Mahango Game Reserve. OW - foraging outside wetlands, SV - short vegetation (including grass) and mud, EV-emergent vegetation (including reeds, rushes and lilies), SW - shallow water, DW - in or over deep water, A - aerial feeders.

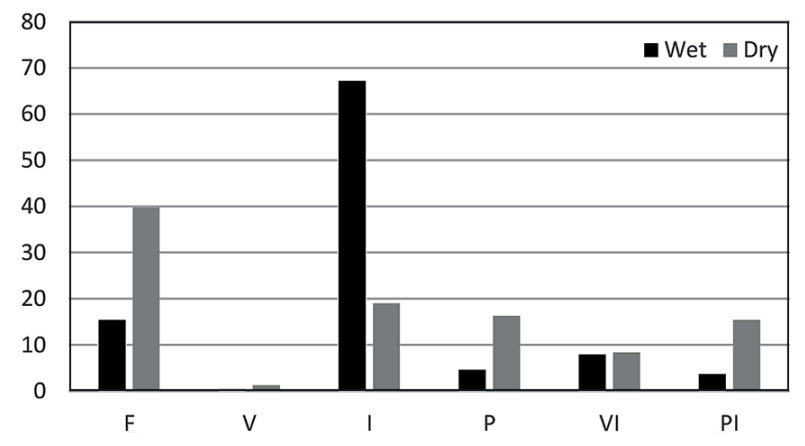

Figure 3

Seasonal differences in the proportions (in percentage of individuals) of main diet guilds of waterbirds in Okavango River in Mahango Game Reserve. F-frugivorous, V-vegetarian, I- insectivorous, $P$ carnivorous, $\mathrm{VI}$ - vegetarian and insectivorous, $\mathrm{Pl}$ - carnivorous and insectivorous.

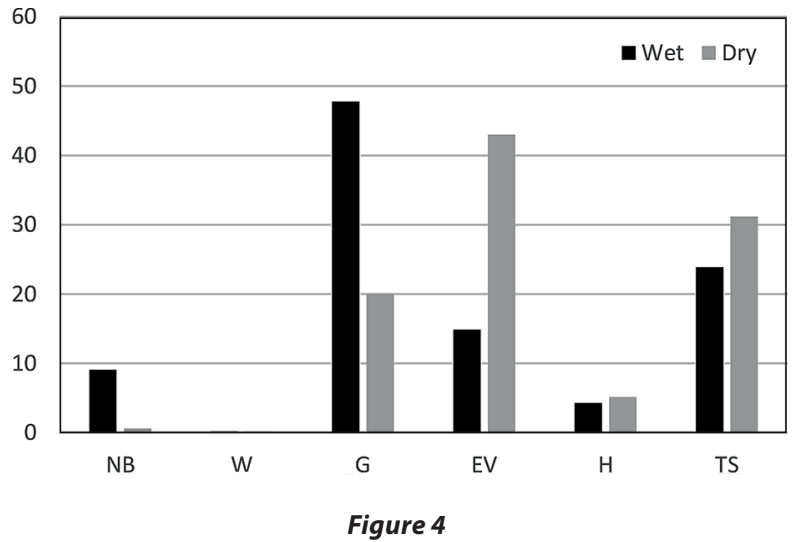

Seasonal differences in the proportions (in percentage of individuals) of main nesting guilds of waterbirds in Okavango River in Mahango Game Reserve. $N B$ - near the bank, $W$ - on water surface, $G$ - on the ground; $V$ in herbaceous vegetation; $T$ - in trees or shrubs; $\mathrm{H}$ - in tree holes

(2012, 2013abc) from Lesotho. In total, 7413 resident pairs and only 74 individuals (about $1.0 \%$ of the avian fauna) of 4 Palearctic species were recorded in that study. This study in the Okavango River recorded much higher numbers, of both species and individuals.

In two artificial lakes in Zimbabwe, wildfowl

(Anseriformes) and waders (Charadriformes) were more common in the dry than wet season, while wading birds (Ciconiiformes) and cormorants (Phalacrocoracidae) remained at a similar level of abundance throughout the year. In general, in the dry season, waterbirds were more common than in the wet season, as in the wet season they disperse to other small water bodies, while in the dry season they congregate in large dams with perenniel water (Mundava et al., 2012). In artificial impoundments in the Western Cape, South Africa (KelejtaSummers et al., 2001, Swanepoel et al., 2009), waterbirds were more common in summer than in winter, but in this region winter is the wet season, while summer is dry.

Several studies have dealt with seasonal variation in a few terrestrial habitats within the savannah and grassland biomes (Kopij, 2001a, b, 2013a, 2014, 2015; Parker, 2014). In these terrestrial habitats, the proportion of Palearctic birds was much lower than that recorded in the Okavango River valley. The Sorensen's coefficient for a comparison between dry and wet seasons varied widely in these habitats, from 0.32 to 0.88 .

During the wet season species such as Reed Cormorant, African Darter, Grey Heron, Great Egret, Black Egret, Yellowbilled Egret, Little Egret, Cattle Egret, Squacco Heron, Greenbacked Heron, Yellow-billed Stork, Sacred Ibis, and African Spoonbill regularly breed in colonies in the Okavango River. However, during the years 2001-2006, such communal breeding sites were not recorded in the Mahango Game Reserve. Most likely these species nested further downstream in the Okavango Delta. As a result of post-breeding dispersal some individuals reach the Mahango Game Reserve (pers. obs.) Hence the number of individuals of those species in the dry season is almost 3 times higher than in the wet season (altogether 1807 birds in the wet and 5327 birds in the dry season). Similarly, White-faced Duck and Spur-winged Goose breed outside the Mahango Game Reserve in the wet season and after this some of them disperse to this reserve. Their numbers are therefore much higher in the dry than in the wet season. Rallids, lapwings and ardeids breed in the wet season in the Mahango Game Reserve, while in the dry season most disperse or migrate to other places (pers. obs.). Hence their numbers are an order of magnitude lower in the dry than in the wet season (altogether 466 in wet seasons, as compared to 4600 in dry seasons).

The Black Crake and African Jacana had stable numbers in the wet season, but in the dry season they showed an increase over the years 2001-2006. Similarly the Goliath Heron and African Openbill Stork showed a decline over the years in the wet season, but an increase in the dry season. Most likely breeding populations of these species were in decline in Mahango Game Reserve, while in the Okavango Delta they could have been in increase in the same period. As a result of their post-natal dispersal, their numbers may increase in Mahango Game Reserve in dry season. The African Skimmer is an intra-African migrant, hence it was not recorded in the wet season; however, in the dry season, when the water level in the river is low, African Skimmers breed in Mahango Game Reserve. Their numbers have shown a steady increase from 190 in 2001 to 480 individuals in 2005. However, numbers of Blackcrowned Night Heron and Grey Heron declined over the years 2001-2007, probably due to competition for food with other ardeid species, which were in increase in that period. 
The proportion of Palearctic migrants to all other birds was an order of magnitude higher in the wet than in the dry season. The ratio of the proportion of Palearctic migrants in the wet season to dry season was $0.82: 0.18(N=1058)$. This relatively high proportion of Palearctic migrants in the austral summer in southern Africa was unexpected. It appears that out of 12 Palearctic waterbird species, 8 remained in their wintering area for the whole year. The results suggest that Common Greenshank remains more regularly in its overwintering grounds for the whole year than any other Palearctic wader species. These figures (Table A1, Appendix) indicate that some individuals, probably the first-year juveniles, do not return to their breeding areas at the end of the wintering season, but remain at their wintering ground for another year, a common feature of long-distance Palearctic migrants (Newton, 2008).

Interestingly, no Palearctic anseriforms were recorded wintering in the study area. Very few were recorded in other places in Namibia (Kolberg, 2012a,b) and elsewhere in southern Africa (Simmons and Allan, 2002; Anderson et al., 2003; Hockey et al., 2005; Kopij, 2013ab). They probably overwinter in southern Africa only occasionally as vagrants, as their main wintering grounds are in west and central Africa.

The Mahango Game Reserve plays an important role in protection of threatened species: it supports 31 waterbird species listed in the Namibian Red Data Book (Simmons et al., 2015). Three of these are globally threatened (Wattled Crane: Vulnerable, Slaty Egret: Vulnerable, African Skimmer: Near Threatened). The reserve also supports 3 mammal, 1 amphibian and 2 fish species listed in the Southern African Red Data Book. The river acts as a linear oasis for a number of bird and mammal species, which would otherwise not have been present in the Kalahari Woodland. It is a wintering area for 11 Palearctic migrants, 4 intra-African migrants and a number of nomadic or semi-nomadic species. This study has shown that the Mahango Game Reserve meets one of the Ramsar criteria: it support more than $1 \%$ of the global population of 2 globally threatened species: the African Skimmer (2.4-4.8\%) and the Slaty Egret (1\%).

\section{ACKNOWLEDGEMENTS}

The following people are thanked for participating in the counts: J Carol, W Hannssen, C Hitch, K Horsti, P Lane, W Le Roux, RM Mashiye, B McGraw, R McKechnie, K Menzt, W Mukena, K Mulimba, J Murrphy, C Orchard, K Price, H \& T Priest, D Sharpe, L Sheehan, S Symmonds, T Cooper and R Urban.

\section{REFERENCES}

ANDERSON MD, KOLBERG H, ANDERSON PC, DINI J and ABRAHAMS A (2003) Waterbird population at Orange River mouth: Reassessment of its Ramsar status. Ostrich 74 1-14.

BIBBY CL, BURGESS ND and HILL DA (1992) Bird Census Techniques. Academic Press, London.

BETHUNES S (1991) Kavango River wetlands. Madoqua 17 (2) 77-112. CUMMING GS, NDLOVU M, MUTUMI GL and HOCKEY PAR
(2013) Responses of an African wading bird community to resource pulses are related to foraging guild and food-web position. Freshwater Biol. 58 79-87. https://doi.org/10.1111/fwb.12040

CUMMING GS, PAXTON M, KING J and BEUSTER H (2012) Foraging guild membership explains variation in waterbird responses to the hydrological regimeof an arid regionflodd-pulse river in Namibia. Freshw. Biol. https://doi. $\operatorname{org} / 10.1111 / j .1365-2427.2012 .02789 . x$

HOCKEY PAR, DEAN WRJ and RYAN PG (eds.) (2005) Roberts' Birds of Southern Africa. John Voelcker Bird Book Fund, Cape Town.

KALEJTA-SUMMERS B., MCCARTHY M and UNDERHILL LG (2001) Long-term-trends, seasonal abundance and energy consumption of waterbirds at Strandfontein, western Cape, South Africa, 1953-1993. Ostrich 72 80-95. https://doi. org/10.2989/00306520109485290

KOLBERG H (2012a) Trends in Namibian Waterbird Populations. 7: Ducks and Geese (1). Lanioturdus 45 (2) 17-22.

KOLBERG H (2012b) Trends in Namibian Waterbird Populations. 7: Ducks and Geese (2). Lanioturdus 45 (3) 15-19.

KOPIJ G (2001a) Birds of Roma Valley, Lesotho. NUL, Roma.

KOPIJ G (2001b) Atlas of birds of Bloemfontein. NUL/Free State Bird Club, Roma/Bloemfontein

KOPIJ G (2012) Avian assemblages of river valleys in Lesotho lowlands, Senque Valley and foothills. Berkut 21 23-30.

KOPIJ G (2013a) Avian assemblages of river gorges in the Maloti/ Drakensberg 'hot spot' region, southern Africa. Zool. Ecol. 23 171182. https://doi.org/10.1080/21658005.2013.830409

KOPIJ G (2013b) Seasonal changes in avian assemblages in Kaokoland (Mopane) Savanna in the Ogongo Game Reserve, north-central Namibia. Int. Sci. Technol. J. Namibia 2 (1) 44-58.

KOPIJ G (2013c) Seasonal and altitudinal variations in an avian assemblagein an iselberg Olea-Buddleia vegetation in the dry Cymbopogon-Themeda grassveld, South Africa. Orn. Observ. 4 158-167.

KOPIJ G (2013d) Distribution, abundance and habitat of Palearctic migrants in Lesotho (Maloti/Drakensberg region). Ornis Svec. 23 123-129.

KOPIJ G (2015) Avian communities of a mixed Mopane-Acacia savanna in the Cuvelei drainage system, north-central Namibia, during the dry and wet season. Ves. Zool. 48 269-274.

MENDELSOHN J and EL OBEID S (2003) Sand and Water. A Profile of the Kavango Region. Struik Publishers, Cape Town.

MENDELSOHN J and EL OBEID S (2004) Okavango River, the Flow of a Lifeline. Struik Publishers, Cape Town.

MENDELSOHN J, VAN DER POST C, RAMBERG L, MURRAYHUDSON M, WOLSKI P and MOSEPELE K (2010) Okavango Delta: Floods of Life. Raison, Windhoek.

MONADJEM A (2000) An avifaunal (Aves) survey of the lower Usuthu River basin, Swaziland. Durban Mus. Nov. 25 25-31.

MUNDAVA J, CARON A, GAIDET N, COUTO FM, COUTO JT, DE GARINE-WICHATITSKY M and MUNDY PJ (2012) Factors influencing long-term and seasonal waterbirds abundance and composition at two adjacent lakes in Zimbabwe. Ostrich 83 (2). https://doi.org/10.2989/00306525.2012.692726

NEWTON I (2008) Migration Ecology of Birds. Academic Press, Waltham (MA, USA).

SIMMONS RE and ALLAN DG (2002) The Orange River avifauna: abundance, richness and comparisons. Ostrich 74 1-14. https://doi. org/10.1080/00306525.2002.11446736

SWANEPOEL T, UNDERHILL LG, HARTEBOTTLE DH, WHEELER MJ and WILLIAMS AJ (2009) Waterbirds at the Theewaterskloof Dam, Western Cape, South Africa, 1993-2008. Ostrich 77 170-174. https://doi.org/10.2989/00306520609485529 


\section{TABLE A1}

Seasonal changes in the numbers of 86 species of water birds in the Okavango River, Mahango Game Reserve over the years 20012006. Dominant species $(>5 \%)$ and subdominant species $(2-5 \%)$ are indicated in bold under $N$ (total number of individual) and $\% \mathrm{D}$ (dominance). Explanations of symbols used to describe guilds: Migr. - acc. to migration activity: R - resident (present throughout the year), RN - resident during breeding, otherwise nomad, LM - resident during breeding season, partial migrant after breeding, $N$ - nomad, AM - intra-Africa migrant, P - Palearctic migrant, V - vagrant. For. - acc. foraging habits: OW - foraging outside wetlands, SV - short vegetation (including grass) and mud, EV - emergent vegetation (including reed, rush and lilies), SW - shallow water, DW- in or over deep water, A - aerial feeders. Diet - acc. bird diet: F - fish, V- vertebrates, I - insects, P - plants, IV - vertebrates and insects, $\mathrm{PI}$ - plants and insects, $\mathrm{O}$ - omnivorous. Nest. - acc. to nesting site selection: $\mathrm{O}$ - near the bank; $\mathrm{W}$ - on water surface, $\mathrm{G}$ - on the ground; $\mathrm{V}$ - emergent vegetation; $\mathrm{H}$ - in tree holes; $\mathrm{T}$ - in trees or shrubs. Wilcoxon's test: ${ }^{*} P<0.05,{ }^{* *} P<0.01$.

\begin{tabular}{|c|c|c|c|c|c|c|c|c|c|c|c|c|}
\hline \multirow{2}{*}{ Species } & \multicolumn{4}{|c|}{ Guilds } & \multicolumn{2}{|c|}{ Wet } & \multicolumn{2}{|c|}{ Dry } & \multicolumn{2}{|c|}{ Chi-square } & \multicolumn{2}{|c|}{ Wilcoxon's } \\
\hline & Migr. & For. & Diet & Nest. & $N$ & $\% \mathrm{D}$ & $N$ & $\% \mathrm{D}$ & $x^{2}$ & $P$ & $T$ & $P$ \\
\hline Little Grebe Tachybaptus ruficollis & LM & 3 & IV & W & 4 & 0.04 & 4 & 0.03 & & & & \\
\hline Reed Cormorant Phalacrocorax africanus & RN & 4 & $\mathrm{~F}$ & $\mathrm{~T}$ & 432 & 4.33 & 1318 & 8.49 & 448.6 & 0.01 & & \\
\hline African Darter Anhinga rufa & LM & 4 & $\mathrm{~F}$ & $\mathrm{~T}$ & 558 & 5.59 & 929 & 5.99 & 92.6 & 0.01 & & \\
\hline Great White Pelican Pelecanus onocrotalus & $\mathrm{N}$ & 3 & F & G & 0 & 0.00 & 1 & 0.01 & & & & \\
\hline Grey Heron Ardea cinerea & $\mathrm{R}$ & 3 & $\mathrm{~F}$ & $\mathrm{~T}$ & 1 & 0.01 & 81 & 0.52 & 78.0 & 0.01 & & \\
\hline Black-headed Heron Ardea melanocephala & $\mathrm{R}$ & 0 & $\mathrm{~V}$ & $\mathrm{~T}$ & 0 & 0.00 & 7 & 0.05 & & & & \\
\hline Goliath Heron Ardea goliath & $\mathrm{R}$ & 3 & $\mathrm{~F}$ & G & 53 & 0.53 & 82 & 0.53 & 6.2 & 0.05 & 2 & 0.1 \\
\hline Purple Heron Ardea pururea & $\mathrm{R}$ & 3 & $\mathrm{~F}$ & $\mathrm{~V}$ & 12 & 0.12 & 10 & 0.06 & 0.2 & $>0.05$ & & \\
\hline Great Egret Egretta alba & $\mathrm{RN}$ & 3 & $\mathrm{~F}$ & $\mathrm{~T}$ & 61 & 0.61 & 274 & 1.77 & 135.4 & 0.01 & 1 & 0.1 \\
\hline Slaty Egret Egretta vinaceigula & LM & 3 & $\mathrm{~F}$ & $\mathrm{~V}$ & 29 & 0.29 & 21 & 0.14 & 1.3 & $>0.05$ & & \\
\hline Black Heron Egretta ardesiaca & LM & 3 & $\mathrm{~F}$ & $\mathrm{~V}$ & 6 & 0.06 & 355 & 2.29 & 337.4 & 0.01 & & \\
\hline Yellow-billed Egret Egretta intermedia & LM & 3 & $\mathrm{~F}$ & $\mathrm{~T}$ & 72 & 0.72 & 28 & 0.18 & 19.4 & 0.01 & & \\
\hline Little Egret Egretta garzetta & $\mathrm{RN}$ & 3 & $\mathrm{~F}$ & $\mathrm{~T}$ & 35 & 0.35 & 369 & 2.38 & 276.1 & 0.01 & 0 & 0.05 \\
\hline Cattle Egret Bubulcus ibis & $\mathrm{RN}$ & 1 & IV & $\mathrm{T}$ & 271 & 2.72 & 161 & 1.04 & 28.0 & 0.01 & 5 & $>0.5$ \\
\hline Squacco Heron Ardeola ralloides & $\mathrm{R}$ & 3 & IV & $\mathrm{V}$ & 244 & 2.45 & 781 & 5.03 & 281.3 & 0.01 & & \\
\hline Green-backed Heron Butorides striata & $\mathrm{R}$ & 2 & IV & $\mathrm{V}$ & 118 & 1.18 & 293 & 1.89 & 74.5 & 0.01 & 0 & 0.05 \\
\hline Rufous-bellied Heron Ardeola rufiventris & $\mathrm{PM}$ & 2 & IV & $\mathrm{V}$ & 21 & 0.21 & 11 & 0.07 & 3.1 & $>0.05$ & 0 & 0.05 \\
\hline $\begin{array}{l}\text { Black-crowned Night Heron Nycticorax } \\
\text { nycticorax }\end{array}$ & $\mathrm{RN}$ & 3 & IV & $\mathrm{T}$ & 117 & 1.17 & 4 & 0.03 & 105.5 & 0.01 & & \\
\hline $\begin{array}{l}\text { White-backed Night Heron Gorsachius } \\
\text { leuconotus }\end{array}$ & $\mathrm{R}$ & 0 & IV & $\mathrm{T}$ & 10 & 0.10 & 7 & 0.05 & 0.5 & $>0.05$ & & \\
\hline Dwarf Bittern Ixobrychus sturmii & $\mathrm{AM}$ & 0 & IV & $\mathrm{V}$ & 2 & 0.02 & 0 & 0.00 & & & & \\
\hline Little Bittern Ixobrychus minutus & $\mathrm{R}$ & 0 & IV & $\mathrm{V}$ & 0 & 0.00 & 12 & 0.08 & 12.0 & 0.01 & & \\
\hline Yellow-billed Stork Mycteria ibis & $\mathrm{RN}$ & 3 & $\mathrm{~V}$ & $\mathrm{~T}$ & 8 & 0.08 & 157 & 1.01 & 134.6 & 0.01 & & \\
\hline African Openbill Anastomus lamelligerus & RN & 3 & $\mathrm{I}$ & $\mathrm{T}$ & 679 & 6.80 & 717 & 4.62 & 1.0 & $>0.05$ & 7 & $>0.5$ \\
\hline Abdim's Stork Ciconia abdimii & $\mathrm{V}$ & 0 & I & 0 & 30 & 0.30 & 0 & 0.00 & 30.0 & 0.01 & & \\
\hline Woolly-necked Stork Ciconia episcopus & RN & 3 & $\mathrm{I}$ & $\mathrm{T}$ & 1 & 0.01 & 0 & 0.00 & & & & \\
\hline Marabou Stork Leptoptilos crumeniferus & $\mathrm{RN}$ & 0 & $\mathrm{C}$ & $\mathrm{T}$ & 0 & 0.00 & 7 & 0.05 & & & & \\
\hline $\begin{array}{l}\text { Saddlebilled Stork Ephippiorhynchus } \\
\text { senegalensis }\end{array}$ & $\mathrm{RN}$ & 3 & $\mathrm{~F}$ & $\mathrm{~T}$ & 4 & 0.04 & 17 & 0.11 & 8.0 & 0.01 & & \\
\hline African Sacred Ibis Threskiornis aethiopicus & $\mathrm{RN}$ & 1 & I & $\mathrm{T}$ & 1 & 0.01 & 469 & 3.02 & 466.0 & 0.01 & & \\
\hline Glossy Ibis Plegadis falcinellus & $\mathrm{RN}$ & 1 & $\mathrm{I}$ & $\mathrm{V}$ & 0 & 0.00 & 1 & 0.01 & & & & \\
\hline African Spoonbill Platalea alba & RN & 3 & $\mathrm{~F}$ & $\mathrm{~T}$ & 0 & 0.00 & 112 & 0.72 & 112.0 & 0.01 & & \\
\hline Hamerkop Scopus umbretta & $\mathrm{R}$ & 3 & $\mathrm{~V}$ & $\mathrm{~T}$ & 27 & 0.27 & 30 & 0.19 & 0.2 & $>0.05$ & & \\
\hline Fulvous Duck Dendrocygna bicolor & RN & 3 & PI & $\mathrm{V}$ & 2 & 0.02 & 0 & 0.00 & & & & \\
\hline White-faced Duck Dendrocygna viduata & $\mathrm{RN}$ & 3 & PI & $\mathrm{V}$ & 318 & 3.19 & 2335 & 15.05 & 1533.5 & 0.01 & 0 & 0.05 \\
\hline White-backed Duck Thalassornis leuconotus & $\mathrm{N}$ & 3 & $\mathrm{P}$ & $\mathrm{V}$ & 2 & 0.02 & 0 & 0.00 & & & & \\
\hline Spur-winged Goose Plectropterus gambensis & $\mathrm{R}$ & 1 & $\mathrm{P}$ & $\mathrm{V}$ & 148 & 1.48 & 2265 & 14.60 & 1857.3 & 0.01 & & \\
\hline Comb Duck Sarkidornis melanotos & $\mathrm{PM}$ & 3 & $\mathrm{P}$ & $\mathrm{H}$ & 83 & 0.83 & 46 & 0.30 & 10.6 & 0.01 & & \\
\hline Egyptian Goose Alopochen aegyptiaca & $\mathrm{LM}$ & 1 & $\mathrm{P}$ & $\mathrm{T}$ & 40 & 0.40 & 47 & 0.30 & 0.6 & $>0.05$ & & \\
\hline African Pygmy Goose Nettapus auritus & $\mathrm{R}$ & 3 & $\mathrm{P}$ & $\mathrm{H}$ & 160 & 1.60 & 105 & 0.68 & 11.4 & 0.01 & 7 & $>0.5$ \\
\hline
\end{tabular}


TABLE A1 (CONT.)

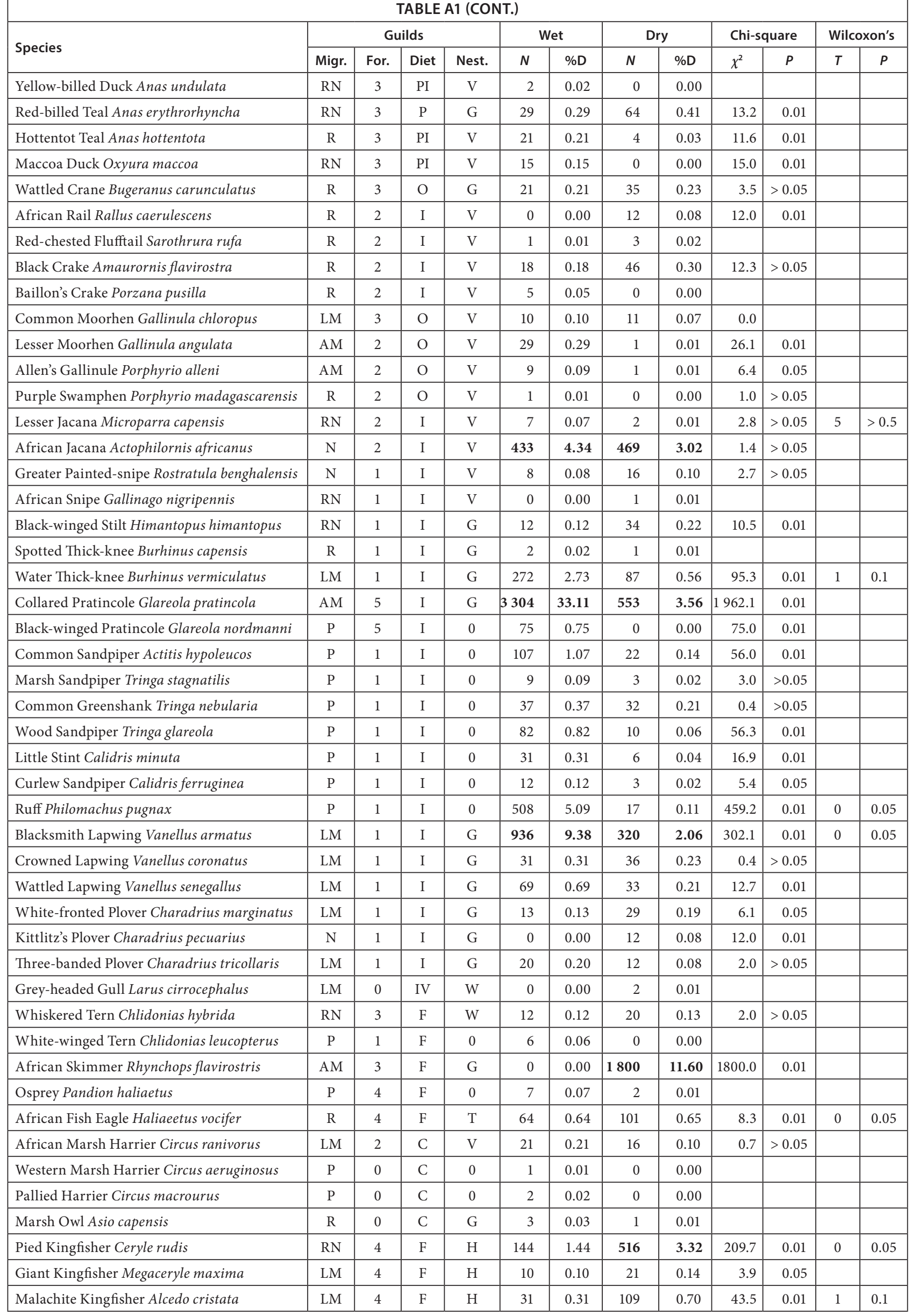

https://doi.org/10.4314/wsa.v45i2.13

Available on website http://www.wrc.org.za

ISSN 1816-7950 (Online) = Water SA Vol. 45 No. 2 April 2019

Published under a Creative Commons Attribution Licence 